\title{
Development and cross-species amplification of microsatellite loci for Puccinellia maritima, an important engineer saltmarsh species
}

\author{
R. Rouger, M. Vallejo-Marin and A.S. Jump
}

Biological and Environmental Sciences, School of Natural Sciences, University of Stirling, Stirling, United Kingdom

Corresponding author: A.S. Jump

E-mail: a.s.jump@stir.ac.uk

Genet. Mol. Res. 13 (2): 3426-3431 (2014)

Received February 8, 2013

Accepted June 14, 2013

Published April 30, 2014

DOI http://dx.doi.org/10.4238/2014.April.30.3

\begin{abstract}
The grass Puccinellia maritima is an important saltmarsh ecosystem engineer exhibiting wide morphological variation, which is partially genetically determined. Nevertheless, nothing is known about its population genetics or how neutral genetic variation is distributed throughout its geographical range. Here, we describe 12 polymorphic microsatellites pooled into two multiplexes for this octoploid species. Assessment of 24 samples from three populations revealed 4 to 29 alleles per locus, with variation in allele presence and abundance between populations. The transferability of these markers is reported based on their cross-amplification in six other Puccinellia species of different ploidy levels.
\end{abstract}

Key words: Microsatellite; Multiplex; Polyploidy; Saltmarsh; Puccinellia maritima 


\section{INTRODUCTION}

Saltmarshes are coastal ecosystems characterised by the presence of salt-tolerant vegetation that is frequently flooded by sea tides (Nottage and Robertson, 2005). Over past centuries, the extent of these coastal ecosystems has been substantially reduced for several reasons, including land reclamation for agriculture, urbanisation, and coastal squeeze between sea defences and rising sea levels (Adam, 2002). Restoration programs have been implemented throughout Europe to counteract this loss.

Puccinellia maritima is a perennial and octoploid saltmarsh plant species (Scott and Gray, 1976). This species is often the dominant plant of the early successional stages of European saltmarshes. P. maritima is considered as an engineer species due to its ability to accumulate and stabilise sediments, thereby creating suitable habitats for the establishment of other saltmarsh plants (Langlois et al., 2001, 2003). This species shows great morphological variation between populations either along the coastline or along the tidal gradient. This variation has been shown to be partially genetically determined through classical genetic studies (Gray et al., 1979; Gray and Scott, 1977, 1980; Gray, 1985). However, the distribution of genetic variation within and between populations of $P$. maritima is poorly understood, whilst gene flow and genetic structuring at regional scales remains unknown, largely due to the lack of variable genetic markers for this species.

Here, we describe 12 newly developed microsatellite markers that will enable further study of the genetic diversity and structure of this species at both local and regional geographic scales, and allow us to develop a greater evidence base for saltmarsh restoration and management.

\section{MATERIAL AND METHODS}

Ten P. maritima individuals from five populations were sampled across the United Kingdom (Walborough: $51^{\circ} 19^{\prime} \mathrm{N}, 2^{\circ} 59^{\prime} \mathrm{W}$; Chalkdock: $50^{\circ} 48^{\prime} \mathrm{N}, 0^{\circ} 52^{\prime} \mathrm{W}$; Lepe: $50^{\circ} 47^{\prime} \mathrm{N}$, $1^{\circ} 21^{\prime} \mathrm{W}$; Abbotts Hall: $51^{\circ} 47^{\prime} \mathrm{N}, 0^{\circ} 51^{\prime} \mathrm{E}$; Goosemoor: 5040'N, $\left.3^{\circ} 27^{\prime} \mathrm{W}\right)$. Genomic DNA was extracted from silica-dried leaves using the ISOLATE Plant DNA Mini Kit (Bioline, London, UK). An equimolar DNA solution was prepared from the 10 samples and sent to Genoscreen (Lille, France) for development of a microsatellite-enriched library using eight different probes (TG, AAC, AGG, ACAT, TC, AAG, ACG, ACTC), and sequencing by 454 GS FLX Titanium (Roche Applied Science, Meylan, France) according to methods described in Malausa et al. (2011).

The resulting reads were analysed with the QDD2 software (Meglécz et al., 2010) to detect microsatellite loci and design primers for each of them. Default parameters of the software were used, apart for the maximum length of polymerase chain reaction (PCR) products for primer design, which was set to $400 \mathrm{bp}$. The selection criteria used for choosing candidate primers for testing were adapted from Lepais and Bacles (2011). First, microsatellites containing the AT motif were discarded due to the difficulty of their amplification (Temnykh et al., 2001), and only di- or tri-nucleotide microsatellites were selected. Candidate primers were grouped into six classes of $50 \mathrm{bp}$ according to the expected size of their PCR products (90140, 140-190, 190-240, 240-290, 290-340, and >340 bp). Four primers from each size class were selected for a first screening of 24 loci. This selection was based on statistics given by 
QDD2, with "A" design with the lowest penalty score being selected whenever possible. Two additional screenings of 24 loci were each conducted by preferentially selecting candidates in the size classes for which less reliable loci were found in the previous screening. Our objective was to obtain a sample of primer pairs spread across size classes that would allow us to maximise the number of loci that could be included in each multiplex PCR (Lepais and Bacles, 2011). Sequence data for each tested locus were submitted to GenBank (http://www.ncbi. nlm.nih.gov/genbank/) under accession numbers KC588847 to KC588900. Each primer pair was run in simplex PCR format using an M13 tailed primer protocol (Schuelke, 2000). PCRs were carried out in a final volume of $10 \mu \mathrm{L}$ containing $1 \mathrm{X}$ Type-it Multiplex PCR Master Mix (Qiagen, Manchester, UK), $0.05 \mu \mathrm{M}$ M13-forward primer, $1 \mu \mathrm{M}$ reverse primer, 1X M13fluorescent dye using four different dyes (6-FAM, HEX, TAMRA, ATTO 565; MWG Operon, Ebersberg, Germany), and approximately 20 ng genomic DNA. PCR cycles were performed on a DNA engine Tetrad ${ }^{\circledR} 2$ Peltier Thermal cycler (Bio-Rad, Hertfordshire, UK) with a starting step of $5 \mathrm{~min}$ at $95^{\circ} \mathrm{C}$ followed by 32 cycles of $30 \mathrm{~s}$ at $95^{\circ} \mathrm{C}, 90 \mathrm{~s}$ at $60^{\circ} \mathrm{C}, 30 \mathrm{~s}$ at $72^{\circ} \mathrm{C}$, and then 8 cycles of $30 \mathrm{~s}$ at $94^{\circ} \mathrm{C}, 45 \mathrm{~s}$ at $53^{\circ} \mathrm{C}, 45 \mathrm{~s}$ at $72^{\circ} \mathrm{C}$, and finishing with a final elongation step of $10 \mathrm{~min}$ at $72^{\circ} \mathrm{C}$. PCR products labelled with different fluorescent dyes were pooled and analysed in an ABI 3730xl sequencer (Applied Biosystems, Warrington, UK). Fragment data were analysed with Peak Scanner (Applied Biosystems). The clarity and exploitability of the signal was assessed by running PCR on seven samples from three populations. Primer pairs showing no amplification, too much stutter, or amplifying monomorphic loci were discarded.

The selected primers were checked for multiplex compatibility using Multiplex Manager (Holleley and Geerts, 2009), and used to design multiplex assays. Multiplex PCRs were carried out in a final volume of $10 \mu \mathrm{L}$ containing 1X Type-it Multiplex PCR Master Mix (Qiagen), variable concentrations of each fluorescently labelled primer (see Table 1), 0.5X Q-solution (Qiagen), and $20 \mathrm{ng}$ genomic DNA. The PCR cycle was $5 \mathrm{~min}$ at $95^{\circ} \mathrm{C}$ followed by 32 cycles of $30 \mathrm{~s}$ at $95^{\circ} \mathrm{C}, 3 \mathrm{~min}$ at $62^{\circ} \mathrm{C}, 30 \mathrm{~s}$ at $72^{\circ} \mathrm{C}$, and a final elongation step of $30 \mathrm{~min}$ at $60^{\circ} \mathrm{C}$.

DNA of eight individuals from three populations (Walborough, Goosemoor, and Nigg Bay: $57^{\circ} 44^{\prime} \mathrm{N} 4^{\circ} 2^{\prime} \mathrm{W}$ ) was amplified with the two designed multiplexes. Alleles were scored using STRand (Veterinary Genetics Laboratory, University of California, http://www.vgl.ucdavis. edu/informatics/strand.php/) with allele binning performed using MsatAllele (Alberto, 2009) modified by M. Vallejo-Marin to allow binning of more than two alleles per locus per individual. Population genetic studies for polyploid species remain challenging since some common statistics, such as expected heterozygosity or deviations from Hardy-Weinberg equilibrium, cannot be computed for polyploids. Consequently, since P. maritima is octoploid (Scott and Gray, 1976), SPAGeDi (Hardy and Vekemans, 2002) was used to determine the number of alleles per locus and the number of private alleles per locus by specifying the ploidy level.

Cross-species amplification was tested in six Puccinellia species differing in ploidy level. Genomic DNA from 10 individuals of P. vahliana (2x, five from Ny-Ålesund, Svalbard, Norway; five from Ringhorndalen, Svalbard, Norway), eight individuals of $P$. angustata (6x, three from Innerholmen, Svalbard, Norway; five from Björndalen, Svalbard, Norway), and two individuals of $P$. svalbardensis (6x, Innerholmen, Svalbard, Norway) was extracted from silica-dried material using the CTAB protocol (Murray and Thompson, 1980). Genomic DNA from two individuals of $P$. convoluta (2x or 4x, one from Tavira, Algarve, Portugal, and one from Alvor, Algarve, Portugal), one individual of P. festuciformis (6x, Quinta do Lago, Algarve, Portugal), and one individual of P. stenophylla (10x, Alvor, Algarve, Portugal) was 
extracted from dry herbarium samples using the ISOLATE Plant DNA Mini Kit (Bioline) according to manufacturer instructions.

\section{RESULTS AND DISCUSSION}

The sequencing strategy yielded 13,253 reads (average length $=284.73 \mathrm{bp}, \mathrm{SD}=$ $117.67 \mathrm{bp}$ ) and 936 microsatellite locus candidates. Of the 72 screened primer pairs, 60 were monomorphic or yielded unreliable bands. Twelve primer pairs showed a clear, repeatable, and polymorphic signal across different samples, and were compatible with multiplex PCR amplification. Two multiplex assays of six primers each were constructed (Table 1).

\begin{tabular}{|c|c|c|c|c|c|c|c|}
\hline Multiplex & Locus & $\begin{array}{c}\text { Repeat } \\
\text { motif }\end{array}$ & $\begin{array}{l}\text { Allele size } \\
\text { range (bp) }\end{array}$ & Primer sequences $\left(5^{\prime} \rightarrow 3^{\prime}\right)$ & $\begin{array}{l}\text { Primer } \\
(\mathrm{nM})\end{array}$ & Dye & $\begin{array}{l}\text { GenBank } \\
\text { accession No }\end{array}$ \\
\hline \multirow[t]{6}{*}{1} & Pm29 & $(\mathrm{AAC})_{6}$ & $132-165$ & $\begin{array}{l}\text { F: CATCCTCGAGAGGGAGAAA } \\
\text { R: ACACATATCAGCCCTCGGT }\end{array}$ & 200 & FAM & KC588874 \\
\hline & Pm61 & $(\mathrm{AAC})_{6}$ & $252-336$ & $\begin{array}{l}\text { F: GAATCATGTGCGAACCTGTG } \\
\text { R: ATCTTCAGCAATGCCTGGAT }\end{array}$ & 200 & FAM & KC588894 \\
\hline & Pm26 & $(\mathrm{AC})_{7}$ & 109-115 & $\begin{array}{l}\text { F: TGGGGACATCGAAATGGTAT } \\
\text { R: TCAAATAGCTGCTGGGAACC }\end{array}$ & 100 & HEX & КС588871 \\
\hline & Pm65 & $(\mathrm{AC})_{7}$ & 226-314 & $\begin{array}{l}\text { F: ATCGTAGGAGATGCACGCTT } \\
\text { R: CGCCAGGAGCTGTTAAATGT }\end{array}$ & 200 & HEX & КC588896 \\
\hline & Pm10 & $(\mathrm{AAC})_{8}$ & $222-234$ & $\begin{array}{l}\text { F: TCAGCTCAAACTCTCAGGCA } \\
\text { R: ACCAAGCTCACCAATCAACC }\end{array}$ & 400 & TAMRA & KC588856 \\
\hline & Pm19 & $(\mathrm{AG})_{9}$ & $312-352$ & $\begin{array}{l}\text { F: GCAGGTTTGATAGAGGCAGG } \\
\text { R: TGGTAACCTAGCGAGCAGTG }\end{array}$ & 400 & TAMRA & KC588865 \\
\hline \multirow[t]{6}{*}{2} & $\operatorname{Pm} 27$ & $(\mathrm{AAG})_{14}$ & $91-208$ & $\begin{array}{l}\text { F: ATCATTGGCCTCTCGTTGTC } \\
\text { R: AGTGTTGGGCGTATAGGCTG }\end{array}$ & 400 & FAM & KC588872 \\
\hline & $\operatorname{Pm} 25$ & $(\mathrm{AGG})_{6}$ & $99-117$ & $\begin{array}{l}\text { F: CTAGTTGCAGCCATGGGATT } \\
\text { R: CCGGAACCATTAGAAGACGA }\end{array}$ & 100 & HEX & KC588870 \\
\hline & Pm34 & $(\mathrm{AAC})_{9}$ & $171-309$ & $\begin{array}{l}\text { F: TGGCAAATTTACACCACGAA } \\
\text { R: GCAAGCAATGAAAACACGAA }\end{array}$ & 100 & HEX & KC588877 \\
\hline & $\operatorname{Pm} 23$ & $(\mathrm{AAC})_{10}$ & $337-352$ & $\begin{array}{l}\text { F: CTTGTTTGGGACTGAAAGGC } \\
\text { R: GACCAGCACGGCATATGTTA }\end{array}$ & 100 & HEX & KC588869 \\
\hline & Pm39 & $(\mathrm{AG})_{9}$ & 243-299 & $\begin{array}{l}\text { F: TTTCGGTCATTAGGATTCGC } \\
\text { R: AAGGCCTGGCTAGATGTGAA }\end{array}$ & 400 & TAMRA & KC588880 \\
\hline & Pm12 & $(\mathrm{AGG})_{6}$ & $213-225$ & $\begin{array}{l}\text { F: GGGTGACTGGGGTGATAAGA } \\
\text { R: AATCCACGAATTTCCACCAA }\end{array}$ & 200 & ATTO-565 & KC588858 \\
\hline
\end{tabular}

Annealing temperature of each multiplex, $\mathrm{Ta}=62^{\circ} \mathrm{C}$.

The number of alleles per locus spanned from 4 to 29 . The maximum number of alleles for an individual at a single locus was eight, which is in accordance with the ploidy level of this species. The number of private alleles varied from 16 to 22 across all loci from eight individuals per population across the three sampled populations (Table 2). The high level of polymorphism and the frequent private alleles demonstrated the efficiency of these loci for studying relatedness between individuals and differentiation between populations.

The results of cross-species amplification differed between species (Table 3). Apart from Pm23, most of the loci amplified in at least one other species. Cross-amplification was most successful in $P$. vahliana, $P$. angustata, and $P$. svalbardensis. However, it should be noted that DNA from P. convoluta, P. festuciformis, and P. stenophylla was extracted from dry herbarium samples, and that amplification from fresh sample DNA may give superior results. 
Table 2. Characteristics of the 12 microsatellite loci described for Puccinellia maritima across 3 populations.

\begin{tabular}{|c|c|c|c|c|c|c|c|c|c|c|c|}
\hline \multirow[t]{2}{*}{ Locus } & \multicolumn{3}{|c|}{ Nigg Bay $(\mathrm{N}=8)$} & \multicolumn{3}{|c|}{ Walborough $(\mathrm{N}=8)$} & \multicolumn{3}{|c|}{ Goosemoor $(\mathrm{N}=8)$} & \multicolumn{2}{|c|}{ Overall $(\mathrm{N}=24)$} \\
\hline & $N_{\mathrm{A}}$ & $N_{\text {I }}$ & PA & $N_{\mathrm{A}}$ & $N_{\mathrm{I}}$ & PA & $N_{\mathrm{A}}$ & $N_{\mathrm{I}}$ & PA & $N_{\mathrm{A}}$ & $N_{\mathrm{I}}$ \\
\hline $\operatorname{Pm} 10$ & 3 & $2-3$ & 0 & 5 & $3-5$ & 0 & 5 & $2-5$ & 0 & 5 & $2-5$ \\
\hline $\mathrm{Pm} 12$ & 3 & $1-3$ & 1 & 3 & $1-3$ & 0 & 3 & $1-3$ & 0 & 4 & $1-3$ \\
\hline Pm19 & 9 & $1-6$ & 2 & 10 & $4-5$ & 5 & 9 & $2-4$ & 3 & 17 & $1-6$ \\
\hline $\operatorname{Pm} 23$ & 4 & $1-4$ & 2 & 2 & $1-2$ & 1 & 3 & $1-3$ & 0 & 6 & $1-4$ \\
\hline $\operatorname{Pm} 25$ & 4 & $1-4$ & 1 & 3 & $1-3$ & 0 & 5 & $1-3$ & 1 & 6 & $1-4$ \\
\hline $\operatorname{Pm} 26$ & 4 & $2-4$ & 0 & 3 & $1-3$ & 0 & 4 & $1-3$ & 0 & 4 & $1-4$ \\
\hline $\operatorname{Pm} 27$ & 15 & $4-7$ & 7 & 10 & $1-3$ & 2 & 19 & $2-5$ & 7 & 29 & $1-7$ \\
\hline $\operatorname{Pm} 29$ & 6 & $2-3$ & 1 & 8 & $2-5$ & 3 & 4 & $1-3$ & 0 & 9 & $1-5$ \\
\hline Pm34 & 13 & $3-8$ & 3 & 12 & $3-6$ & 2 & 10 & $3-6$ & 2 & 18 & $3-8$ \\
\hline Pm39 & 8 & $2-5$ & 2 & 9 & $1-6$ & 2 & 16 & $1-5$ & 8 & 21 & $1-6$ \\
\hline Pm61 & 5 & $1-3$ & 0 & 6 & $2-4$ & 1 & 7 & $3-5$ & 1 & 8 & $1-5$ \\
\hline Pm65 & 5 & $2-5$ & 0 & 6 & $2-4$ & 0 & 6 & $3-5$ & 0 & 6 & $2-5$ \\
\hline Overall & 79 & - & 19 & 77 & - & 16 & 91 & - & 22 & 133 & - \\
\hline
\end{tabular}

$N_{\mathrm{A}}=$ number of alleles; $N_{\mathrm{I}}=$ number of alleles per individual; $\mathrm{PA}=$ number of private alleles.

\begin{tabular}{|c|c|c|c|c|c|c|c|c|c|c|c|c|c|c|c|c|c|c|}
\hline \multirow[t]{2}{*}{ Locus } & \multicolumn{3}{|c|}{$\begin{array}{l}\text { P. vahliana } \\
(\mathrm{N}=10)\end{array}$} & \multicolumn{3}{|c|}{$\begin{array}{l}\text { P. angustata } \\
(\mathrm{N}=8)\end{array}$} & \multicolumn{3}{|c|}{$\begin{array}{l}\text { P. svalbardensis } \\
(\mathrm{N}=2)\end{array}$} & \multicolumn{3}{|c|}{$\begin{array}{l}\text { P. convolute } \\
(\mathrm{N}=2)\end{array}$} & \multicolumn{3}{|c|}{$\begin{array}{l}\text { P. festuciformis } \\
(\mathrm{N}=1)\end{array}$} & \multicolumn{3}{|c|}{$\begin{array}{l}\text { P.stenophylla } \\
(\mathrm{N}=1)\end{array}$} \\
\hline & $\mathrm{S}$ & $N_{\mathrm{A}}$ & $\mathrm{NP}$ & $\mathrm{S}$ & $N_{\mathrm{A}}$ & $\mathrm{NP}$ & $\mathrm{S}$ & $N_{\mathrm{A}}$ & $\mathrm{NP}$ & $\mathrm{S}$ & $N_{\mathrm{A}}$ & $\mathrm{NP}$ & $\mathrm{S}$ & $N_{\mathrm{A}}$ & $\mathrm{NP}$ & $\mathrm{S}$ & $N_{\mathrm{A}}$ & NP \\
\hline Pm10 & + & 2 & 10 & + & 2 & 8 & + & 3 & 2 & + & 7 & 2 & - & 0 & 0 & + & 1 & 1 \\
\hline Pm12 & + & 1 & 5 & + & 1 & 4 & + & 2 & 2 & - & 0 & 0 & - & 0 & 0 & - & 0 & 0 \\
\hline Pm19 & + & 4 & 5 & - & 1 & 3 & + & 3 & 2 & - & 0 & 0 & - & 0 & 0 & - & 0 & 0 \\
\hline $\operatorname{Pm} 23$ & - & 0 & 0 & - & 0 & 0 & - & 0 & 0 & - & 0 & 0 & - & 0 & 0 & - & 0 & 0 \\
\hline $\operatorname{Pm} 25$ & + & 1 & 5 & + & 2 & 4 & + & 2 & 2 & + & 3 & 2 & - & 0 & 0 & - & 0 & 0 \\
\hline Pm26 & + & 2 & 10 & + & 2 & 8 & + & 2 & 2 & + & 1 & 1 & - & 0 & 0 & - & 0 & 0 \\
\hline $\operatorname{Pm} 27$ & + & 1 & 9 & + & 2 & 7 & + & 1 & 2 & - & 0 & 0 & - & 0 & 0 & - & 0 & 0 \\
\hline Pm29 & + & 2 & 10 & + & 2 & 8 & + & 4 & 2 & + & 4 & 2 & - & 0 & 0 & - & 0 & 0 \\
\hline Pm34 & + & 1 & 5 & - & 1 & 1 & + & 1 & 2 & + & 2 & 2 & - & 0 & 0 & - & 0 & 0 \\
\hline Pm39 & - & 0 & 0 & - & 0 & 0 & + & 2 & 2 & - & 0 & 0 & - & 0 & 0 & - & 0 & 0 \\
\hline Pm61 & + & 1 & 5 & + & 3 & 4 & + & 1 & 2 & + & 1 & 1 & - & 0 & 0 & - & 0 & 0 \\
\hline Pm65 & + & 1 & 5 & - & 1 & 3 & + & 2 & 2 & + & 1 & 1 & - & 0 & 0 & - & 0 & 0 \\
\hline
\end{tabular}

$\mathrm{S}=$ amplification success; $N_{\mathrm{A}}=$ number of alleles across all individuals amplified; $\mathrm{NP}=$ number of samples positively amplified. The amplification was considered as successful when half or more of the samples showed amplification.

In conclusion, the 12 polymorphic microsatellite loci described here will be highly useful to study the population genetics of P. maritima across a broad range of applications in molecular ecology and habitat restoration. Moreover, cross-amplification of these markers demonstrates their utility for research in congeneric species, such as $P$. svalbardensis, a rare endemic plant from the island of Svalbard, Norway.

\section{ACKNOWLEDGMENTS}

Research supported by the Esmée Fairbairn Foundation, the University of Stirling, and the Royal Society for the Protection of Birds. We thank Olivier Lepais for technical advice. We are most grateful to Pernille Bronken Eidesen from the University Centre in Svalbard, Longyearbyen, Norway, and Maria Manuela David from the Herbarium of the University of Algarve, Faro, Portugal, for sample collections of related Puccinellia species. 


\section{REFERENCES}

Adam P (2002). Saltmarshes in a time of change. Environ. Conserv. 29: 39-61.

Alberto F (2009). MsatAllele_1.0: An R package to visualize the binning of microsatellite alleles. J. Hered. 100: 394-397.

Gray AJ (1985). Adaptation in perennial coastal plants - with particular reference to heritable variation in Puccinellia maritima and Ammophila arenaria. Plant Ecol. 61: 179-188.

Gray AJ and Scott R (1977). Puccinellia maritima (Huds.) Parl.: (Poa maritima Huds.; Glyceria maritima (Huds.) Wahlb.). J. Ecol. 65: 699-716.

Gray AJ and Scott R (1980). A genecological study of Puccinellia maritima Huds. (Parl.). I. Variation estimated from single-plant samples from British populations. New Phytol. 85: 89-107.

Gray AJ, Parsell RJ and Scott R (1979). The Genetic Structure of Plant Populations in Relation to the Development of Salt Marshes. In: Ecological Processes in Coastal Environments. 1st European Ecological Symposium and 19th Symposium of The British Ecological Society, Norwich, 43-61.

Hardy OJ and Vekemans X (2002). SPAGeDi: a versatile computer program to analyse spatial genetic structure at the individual or population levels. Mol. Ecol. 2: 618-620.

Holleley CE and Geerts PG (2009). Multiplex Manager 1.0: a cross-platform computer program that plans and optimizes multiplex PCR. Biotechniques 46: 511-517.

Langlois E, Bonis A and Bouzillé JB (2001). The response of Puccinellia maritima to burial: A key to understanding its role in salt-marsh dynamics? J. Veg. Sci. 12: 289-297.

Langlois E, Bonis A and Bouzillé JB (2003). Sediment and plant dynamics in saltmarshes pioneer zone: Puccinellia maritima as a key species? Estuar. Coast. Shelf S. 56: 239-249.

Lepais O and Bacles CF (2011). Comparison of random and SSR-enriched shotgun pyrosequencing for microsatellite discovery and single multiplex PCR optimization in Acacia harpophylla F. Muell. Ex Benth. Mol. Ecol. Resour. 11: 711-724.

Malausa T, Gilles A, Meglecz E, Blanquart H, et al. (2011). High-throughput microsatellite isolation through 454 GS-FLX Titanium pyrosequencing of enriched DNA libraries. Mol. Ecol. Resour. 11: 638-644.

Meglécz E, Costedoat C, Dubut V, Gilles A, et al. (2010). QDD: a user-friendly program to select microsatellite markers and design primers from large sequencing projects. Bioinformatics 26: 403-404.

Murray MG and Thompson WF (1980). Rapid isolation of high molecular weight plant DNA. Nucleic Acids Res. 8: 43214325.

Nottage AS and Robertson PA (2005). Saltmarsh Formation and Development. In: The Saltmarsh Creation Handbook: A Project Manager's Guide to the Creation of Saltmarsh and Intertidal Mudflat the Royal Society for the Protection of Birds. Sandy and CIWEM, London, 10.

Schuelke M (2000). An economic method for the fluorescent labeling of PCR fragments. Nat. Biotechnol. 18: 233-234.

Scott R and Gray AJ (1976). Chromosome number of Puccinellia maritima (Huds.) Parl. in the British Isles. Watsonia 11: 53-57.

Temnykh S, DeClerck G, Lukashova A, Lipovich L, et al. (2001). Computational and experimental analysis of microsatellites in rice (Oryza sativa L.): frequency, length variation, transposon associations, and genetic marker potential. Genome Res. 11: 1441-1452. 